\title{
'Can I write to you about Ireland?': John Vaizey, the Ford Foundation and Irish educational policy change, 1959-1962 [document study]
}

\section{Peter Murray}

To cite this article: Peter Murray (2012) 'Can I write to you about Ireland?': John Vaizey, the Ford Foundation and Irish educational policy change, 1959-1962 [document study], Irish Educational Studies, 31:1, 67-75, DOI: 10.1080/03323315.2011.601889

To link to this article: https://doi.org/10.1080/03323315.2011.601889

曲 Published online: 14 Nov 2011.

Submit your article to this journal $\widetilde{ }$

Џ Article views: 312

Q View related articles $\longleftarrow$

Citing articles: 3 View citing articles 5 


\title{
'Can I write to you about Ireland?': John Vaizey, the Ford Foundation and Irish educational policy change, 1959-1962 [document study]
}

\author{
Peter Murray* \\ Department of Sociology, NUI Maynooth, Co. Kildare, Ireland
}

\begin{abstract}
During the 1960s a paradigm shift occurred within Irish education thanks to the penetration of the Republic's system by the OECD-sponsored economics of education. The 1965 publication of Investment in Education was the key event in this change. The document reproduced and contextualised here demonstrates how this penetration process had begun as early as the late 1950s. It was pressed forward not only by international organisations like OECD and its OEEC predecessor but also by powerful private US agencies like the Ford Foundation. As leader of the team that produced Investment in Education, Patrick Lynch is the figure primarily associated with the rise of the economics of education in Ireland. Here the key mobilising role played by Lynch's English friend and collaborator, John Vaizey, through a combination of elite network contacts within the world of international policy analysis and personal knowledge of the Irish scene, is highlighted.
\end{abstract}

Keywords: economics of education; policy networks; paradigm shift; Organisation for European Economic Cooperation (OEEC); Organisation for Economic Cooperation and Development (OECD); Ford Foundation

\section{Introduction to the document}

Revisiting the seminal Investment in Education report (Department of Education 1965), Patrick Lynch began by recalling an incident that occurred about a decade before its publication. Then John Vaizey had come into his room in Peterhouse College, Cambridge, to announce that he had 'just invented a new subject and was calling it "The Economics of Education" (Lynch 1998, 3). After obtaining a double first at Cambridge, Vaizey had begun his career as an economist with a study of the British brewing industry. Connections made in the course of this early work led to his being commissioned to write, in collaboration with Lynch, one of the volumes of the history of Guinness's brewery that were to mark its Dublin bicentenary (Lynch and Vaizey 1960). The time Vaizey spent 'working with uncatalogued and unsorted archives' in 1950s Dublin meant that 'through the Irish book I got to know Ireland well' (Vaizey 1986, 123-4). His work on education was developing simultaneously, with the result that 'I became an Expert on that somewhat esoteric but increasingly fashionable subject ... [and] was drawn increasingly to Paris to work with international organisations' (Vaizey 1986, 123). In November 1959 Vaizey combined his experiences of Ireland with his economic expertise on education to write the letter that is reproduced here (see Appendix).

*Email: Peter.Murray@nuim.ie 
The recipient of the letter was Stanley Gordon, an officer of the Ford Foundation in New York. Both Gordon and Vaizey were part of a personal and professional network that had developed around the close working links between leading US private foundations and the Paris-based Organisation for European Economic Cooperation (OEEC) (Gemelli 1996). An Office for Scientific and Technical Personnel (OSTP), established within OEEC in the wake of the October 1957 launch of the first Sputnik satellite by the Soviet Union, had become the driving force behind a push, not only to increase the supply of scientists and technologists, but also to secure recognition among policymakers for the role of education as a key factor in promoting economic growth (Papadopoulos 1994, 21-33). Becoming an OEEC member had been a condition attached to the receipt of Marshall Aid but minimal involvement was characteristic of much of Ireland's interaction with the organisation for its first decade (Murray 2005). As economic and social crisis prompted a reappraisal of Irish policies from the mid-1950s, however, a more positive engagement began to emerge. Having the state's provision for education in mathematics and science reviewed by two external OSTP-appointed experts in October 1959 was one manifestation of this change (Murray 2009, 148-50).

As this OSTP review process was proceeding, a substantial Irish funding application was being considered by the Ford Foundation. In April 1959 reports reached the Department of the Taoiseach from New York that the Ford Foundation 'seemed prepared to consider economic aid' to Ireland. When other departments were circulated with this information, the Department of Finance put forward the idea of seeking grant aid to establish an economic research centre. As meetings of department secretaries and diplomats advanced the idea, it was judged best to submit the application through a non-governmental body, and the Statistical and Social Inquiry Society of Ireland (SSISI) took on the role of the centre's sponsor. The application was received by the Ford Foundation in late August and was discussed at a luncheon meeting in its offices on 9 October. Present on the Irish side were Frank Aiken, the Minister for External Affairs, T.K. Whitaker, Secretary of Finance and an Honorary Secretary of SSISI, J.J. McElligott, Whitaker's Finance predecessor and now Governor of the Central Bank, as well as two diplomats based in New York Frederick Boland and Jack Conway.

While the Irish side came away from the meeting in an optimistic mood, ${ }^{1}$ the supporting documentation subsequently sent from Dublin seems to have raised as many questions as it answered for Foundation officers. Moreover the International Affairs Division was reluctant to become involved with yet another country. Reviewing the material in December, Stanley Gordon wondered whether 'the institute, rather than being mediocre, would be high powered and influential in a fresh way'. He recommended either 'a very neutral note to Whitaker indicating that early action is not practicable and that ... [a] member of the Foundation staff will try and pay a visit during the coming year' or, 'if, on the other hand, it is decided that the Foundation should stretch to give more active consideration', taking the immediate step of communicating with John Vaizey, 'who wrote such a good letter to me about Ireland a month or so ago'. ${ }^{2}$

In his letter ${ }^{3}$ Vaizey had dealt in turn with '1) the economic and political situation, 2) the state of the Universities in relation to education, 3) hopeful and helpful people, 4) the proposed Institute, and 5) how we might break into education'. For Vaizey, Ireland's economy was indissolubly linked with that of the UK while 
inefficiency in agriculture and industry underlay its recurrent economic crises. A new realism was emerging among politicians and civil servants but had to struggle against the power of a church 'responsible for a terrible education system' and of a backward-looking nationalism exemplified by Irish language revival policy. Turning to the universities, Vaizey stressed their poverty. Of his fellow economists, he wrote: 'they all teach inordinately, their salaries are so low that they have to hold innumerable jobs and hardly any of them do any research'. However 'the innate quality of the academic staff is high (no other employment opportunities probably explains a lot)' and their existing deficiencies were curable by adequate time and money.

Appearing on Vaizey's list of 'hopeful and helpful people' were T.K. Whitaker, M.D. McCarthy (Director of the Central Statistics Office) and two UCD economists Patrick Lynch and George O'Brien. These four were linked through SSISI but they lacked 'coherent research', 'a forum for debate and dissemination of their ideas' and with the exceptions of Charles Carter and Vaizey himself - 'outside informed experts'. The proposed economics institute could supply these wants as well as being 'above all ... a means of educating the informed public (members of the Dail included) in the realities of the Irish situation'.

Education should be a priority area of study - 'in its present state it is an immense handicap to the country and above all to the individual emigrant who can only go to England in an unskilled capacity'. While the lower echelons of the clergy were scathingly disparaged by Vaizey, he wished to avoid a clash with the Catholic Church - although the programme of comparative economics of education research taking in the English and Northern Irish systems that he (and Lynch) were contemplating underlined the serious shortcomings associated with the southern combination of a controlling church and a passively deferential state. Throughout the letter the Northern Ireland education system was presented as immensely superior to its southern counterpart (see Patterson 2002, 123-6 and 166-7).

With its 'ray of light', Vaizey's letter provided a narrative - an inward looking country beginning to move towards integration with the Atlantic Community (Berghahn 2001) under guidance from an enlightened group that was struggling to overcome entrenched resistance to necessary change - around which subsequent recommendations that the Foundation should support the Irish application were framed by its staff. Another key point of reference in this process was OSTP, with whom Vaizey was working and from whom the Foundation obtained all the reports written in the course of the 1959 review of mathematics and science education in Ireland. ${ }^{4}$ To OEEC, Ford Foundation officers attributed the conclusions that 'the time is now propitious to get at Ireland's problem through education' and that 'the improvement of economic and social research and training programs would establish the best base on which further educational steps could be taken'. 5

After the Economic Research Institute (ERI) became operational, Vaizey continued to be a source of information and comment for the Ford Foundation on how the new institute was taking shape. In September 1960, when he complained of a lack of attention to the economics of education and an over-emphasis on econometrics, Shepard Stone, head of the International Affairs Division, raised the issue with T.K. Whitaker when the two met while Whitaker was in the USA attending World Bank meetings. ${ }^{6}$ When a group of Irish lay Catholic school proprietors showed a precocious - and officially unwelcome (Murray 2010) - interest 
in the economics of education, Vaizey advised its Honorary Secretary, Patrick Cannon, to send the report on Irish educational investment it published in May 1962 to Stone. ${ }^{7}$ This was quickly followed up with ERI Director R.C. Geary by Matthew Cullen, the Ford Foundation officer responsible for monitoring the Institute's progress:

\begin{abstract}
I have just received a copy of a study of post-primary education in Ireland, recently undertaken by the Federation of Irish Secondary Schools, and I find it a very interesting effort. It points out especially the lack of adequate data and statistics on educational enrolment, manpower needs, and the like and points also to the need for planning in the educational area. I wonder have you seen it and what you think of it. Have there been any further developments since my visit to Ireland in yours and Mr. Whitaker's attempts to get someone interested in this field?
\end{abstract}

Hopeful that the success of the ERI could be repeated for other Irish projects, senior civil servants in Dublin were anxious 'to preserve the interest and good-will of the Ford Foundation' by responding positively. The reply from T.K. Whitaker on 4 July informed Cullen of an Irish economics of education initiative about to be taken outside the ambit of the ERI - a firm government commitment had now been made to carry out the study that would produce Investment in Education. ${ }^{8}$

From 1960 OSTP had sponsored an international Study Group in the Economics of Education of which Vaizey was a leading light. As OEEC was being transformed into the Organisation for Economic Cooperation and Development (OECD) with member states from beyond Europe, it organised a conference on Economic Growth and Investment in Education held in Washington in October 1961. The study group developed a theoretical rationale for educational expansion while the Washington conference was a key moment in the dissemination of these ideas to a wider audience of senior policymakers (Papadopoulos 1994, 32-42; O'Connor 1986, 62-3). In Washington, the Irish delegates - an Assistant Secretary from Finance and another from Education - were presented with an OECD proposal entitled 'Pilot Studies on Long-Term Needs for Educational Resources in Economically Developed Country'. Their positive reception of the proposal was repeated by the secretaries of their respective departments on their return home. ${ }^{9}$ During the closing months of 1961 wider discussion on carrying out in Ireland the kind of pilot study OECD envisaged got under way involving the departments of the Taoiseach, Agriculture, Education, Industry and Commerce, External Affairs as well as the Central Statistics Office. Support for the proposal was unanimous and planning for the study got under way early in $1962 .^{10}$

Most discussion at the planning meetings centred on the question of the expertise needed to carry out the envisaged study. Initially a necessity to source this from outside the country was perceived, but, consulted by C.H. Murray of the Department of Finance in April, Vaizey was unable to suggest anyone who might be available to fill the team leader position - 'economists were very scarce and economists qualified to undertake a study of educational needs and resources were doubly scarce'. The 'possibilities of a part-time assignment' were then turned to 'for this to be at all workable the man in question would have to be resident in this country ... he [Vaizey] suggested that we might consider the question of securing the release of a university academic from his university work'. A project planning meeting of Irish and OECD officials on the same day was informed that the 
Organisation would consider it vital that the project leader be a national of the country carrying out the study'. ${ }^{11}$ Subsequently Patrick Lynch was identified as the preferred candidate for this role and his release by UCD was secured. In this manner Lynch came to direct a study of the economics of Irish education that he and Vaizey had been 'keen' that the new ERI should carry out almost three years earlier.

With the project directed by Lynch getting under way, Ford Foundation urging of educational research on the ERI ended. It was not until the 1970s, with the arrival of A. Dale Tussing, that what had by then become the Economic and Social Research Institute (ESRI) became actively involved in economics of education studies (Tussing 1988). As the pace of Irish educational change quickened in the direction he desired (Walsh 2009), Vaizey's role changed from one of private influence to that of public pronouncement. He contributed an article to the Irish Journal of Education (Vaizey 1967) having earlier, in February 1964, inaugurated a lecture series at St. Patrick's College, Drumcondra, on the theme of 'Contemporary Developments in Education'. The Taoiseach, Sean Lemass, took the chair at Vaizey's lecture and the speech he delivered after the lecturer's address announced a significant new educational policy departure - the provision for the first time of a scheme of building grants to Irish secondary schools. ${ }^{12}$

\section{Conclusion}

Around the time that Vaizey's letter was written a new set of interlocking core elements, that broke with the cultural, political and religious aspirations which had fuelled the nationalist struggle for Irish self-government and shaped government policies in the early decades of independence, were emerging at the heart of Irish public policymaking. These were (and still are) European Economic Community membership, the attraction of inward investment by transnational corporations servicing the European market from an Irish base and the gearing of education to create a labour force that meets the requirements of such investors. The two iconic documentary landmarks of this fundamental shift in strategy are Economic Development (Department of Finance 1958) and Investment in Education (Department of Education 1965). External and internal influences reinforced one another in contributing to the process of change.

Between 1958 and 1965 interaction, first with the OSTP of OEEC and later with the OECD, eroded the defensive isolation of the Department of Education. From the middle of 1961 the preparation of the Second Programme for Economic Expansion did what international experts had been urging Irish policymakers to do by integrating education into economic planning. Changing the status of education from an unproductive form of social spending to a vital return-generating investment in human capital formation opened the way to sustained improvement in government funding (albeit from a very low base). This was accompanied by the effective ending in the second half of 1961 of resistance to external expert input into Irish policymaking at the top of the Department of Education. Writing privately to T.K. Whitaker in May 1962 in the wake of the successful ERI funding application on educational projects that might be proposed to the Ford Foundation for support, that department's secretary, Tarlach O'Raifeartaigh, who had until mid-1961 remained highly sceptical about initiatives involving OECD experts (Murray 2009, 150-4), indicated the extent of the resultant transformation: 
It is only during the last four or five years that we have managed to struggle to our feet here and look around us at all. It was a sorry story $-25 \%$ of our primary teachers untrained, and that position getting steadily worse, the school building problem also getting steadily worse, no push forward in science teaching in the secondary schools, the universities neglected and losing heart, continual recriminations on all sides about salaries and what not ... this situation is well on the way out and ... now we can think in terms of planning. ${ }^{13}$

The bridge between a general commitment to planning and a concrete programme of action to expand and reorient the Irish education system was to be supplied by the OECD-initiated pilot study team headed by Vaizey's friend Lynch that produced Investment in Education. Perhaps owing as much to the chronic difficulty it experienced in recruiting and retaining qualified economic researchers as to disinterest in education (Kennedy 1993), the ERI did not, in its early years, play the role of educational change catalyst that Vaizey had envisaged for it in his letter to Gordon. Nonetheless Vaizey's letter provides a striking sketch of O'Raifeartaigh's 'sorry story' of the Irish education system at the end of the 1950s and vividly illuminates the wider societal context within which it functioned. On the fiftieth anniversary of the appearance of the history of Guinness's brewery that had provided its author with the opportunity for sustained observation of Irish conditions, its publication seems timely.

\section{Notes}

1. National Archives of Ireland (NAI) Department of Taoiseach S16,705 A, TKW[hitaker] note on luncheon meeting with FF officers, New York, 7 October 1959; copy of J. Conway, Consul General, New York to C. Cremin, Secretary, Department of External Affairs, 13 October 1959.

2. Ford Foundation Archives (FFA) Reel No. 620, Grant No. PA 60-285, Section 4, memo, S. Gordon to J. McDaniel, 18 December 1959.

3. FFA Reel No. 620, Grant No. PA 60-285, Section 4, correspondence, J. Vaizey, Oxford to S. Gordon, Ford Foundation, 1 November 1959.

4. FFA Reel No. 620, Grant No. PA 60-285, Section 4, correspondence, J. Pognan, Office for Scientific and Technical Personnel, Organisation for European Economic Cooperation to S. Stone, Ford Foundation, 3 March 1960; J. Vaizey, 'Ireland', 3 March 1960.

5. FFA Reel No. 620, Grant No. PA 60-285, Section 4, memo, International Affairs 'Economic Research Institute, Dublin', 8 April 1960, docket excerpt International Affairs to Executive Committee 'Economic Research Institute, (Dublin) Development Research and Training', 5 September 1960.

6. FFA Reel No. 620, Grant No. PA 60-285, Section 4, letter, S. Stone, Ford Foundation to J. Vaizey, University of London Institute of Education, 28 September 1960.

7. FFA Log File L62-554, P. Cannon, Federation of Irish Secondary Schools to S. Stone, Ford Foundation, 20 June 1962; P. Cannon to M. Cullen, Ford Foundation, 3 July 1962.

8. NAI Department of Finance 2001/3/775, copy of M. Cullen, Ford Foundation to R.C. Geary, Director, Economic Research Institute, 13 June 1962, T.K. Whitaker to M. Cullen, 4 July 1962.

9. NAI Department of Finance 2001/3/546, Note of Meeting, 31 October 1961.

10. See NAI Department of Finance 2001/3/546 and NAI Department of Finance 2001/3/775 for inter-departmental correspondence.

11. NAI Department of Finance 2001/3/775, Note of Meeting (with Vaizey), 17 April 1962; Conference in Department of Education, 17 April 1962, OECD Project: Pilot Study on Long-Term Needs for Educational Resources in Advanced Countries.

12. See NAI Department of Taoiseach 97/9/1680 for draft and final versions of 'Speech by Mr. Sean F. Lemass, Taoiseach, following address by Mr. John Vaizey on "Economics of 
Education", St. Patrick's Training College, Drumcondra; Thursday, the 13th February, 1964'.

13. NAI Department of Finance 2001/3/775, T. O'Raifeartaigh, Secretary, Department of Education to T.K. Whitaker, Secretary, Department of Finance, 4 May 1962.

\section{Notes on contributor}

Peter Murray is a lecturer in the Department of Sociology in NUI Maynooth, Ireland. His main areas of interest are in health, work, politics and the modern state. He has a particular interest in the use of archival and documentary resources in social science research. His current research focus is on the interaction between external and internal forces in the changing of Irish, ideas, institutions and policies between Marshall Aid (1948-51) and EEC entry (1973).

\section{References}

Berghahn, V. 2001. America and the intellectual cold wars in Europe: Shepard Stone between philanthropy, academy and diplomacy. Princeton, NJ: Princeton University Press.

Department of Education. 1965. Investment in education. Dublin: Stationery Office.

Department of Finance. 1958. Economic development. Dublin: Stationery Office.

Gemelli, G. 1996. American influence on European management education: The role of the Ford Foundation. In Management education and competitiveness: Europe, Japan and the United States, ed. R.P. Amdam, 38-68. London: Routledge.

Kennedy, K.A. 1993. R.C. Geary and the ESRI. Economic and Social Review 24, no. 3: 225-45.

Lynch, P. 1998. Societal change and education: Investment in education revisited. Issues in Education 3: 3-7.

Lynch, P., and J. Vaizey. 1960. Guinness's brewery in the Irish economy 1759-1876. Cambridge: Cambridge University Press.

Murray, P. 2005. Ireland and the productivity drive of post-war Europe. In The Lemass era: Politics and society in the era of Sean Lemass, ed. B. Girvin and G. Murphy, 66-81. Dublin: UCD Press.

Murray, P. 2009. Facilitating the future? US aid, European integration and Irish industrial viability, 1948-73. Dublin: UCD Press.

Murray, P. 2010. Educational developmentalists divided? Patrick Cannon, Patrick Hillery and the economics of education in the early 1960s. Economic and Social Review 41, no. 3: 32548.

O'Connor, S. 1986. A troubled sky: Reflections on the Irish educational scene 1957-1968. Dublin: St. Patrick's College Education Research Centre.

Papadopoulos, G. 1994. Education 1960-1990: The OECD perspective. Paris: Organisation for Economic Cooperation and Development.

Patterson, H. 2002. Ireland since 1939: The persistence of conflict. Oxford: Oxford University Press.

Tussing, A.D. 1988. Social science in the land of saints and scholars: Policy research in Ireland. Evaluation and Program Planning 11, no. 2: 161-7.

Vaizey, J. 1967. Education and the Irish economy. Irish Journal of Education 1, no. 2: 113-23.

Vaizey, J. 1986. Scenes from institutional life and other writings. London: Weidenfeld and Nicholson.

Walsh, J. 2009. The politics of expansion: The transformation of education policy in the Republic of Ireland, 1957-72. Manchester: Manchester University Press. 


\section{Appendix: Text of letter \\ John Vaizey, Oxford University, to Stanley Gordon, Ford Foundation}

My dear Mr. Gordon,

19 Beaumont Street Oxford Nov. 1, 1959

Can I write to you about Ireland? I will not bore you with a recital of its economic position, the question of religion, emigration, the position of Irish as a language, the fanatical matter of the Border and so on. Wherever you look it's hopeless! However, a ray of light ... In this letter I shall deal 1) with the economic and political situation, 2) the state of the universities in relation to education, 3) hopeful and helpful people, 4) the proposed Institute and 5) how we might break into education.

1) Ireland's economy is indissolubly linked with the UK by the force of emigration (4060,000 a year), a common banking and currency system, exports and imports (about 80\% either way), capital ownership. It is therefore analogous to a poor part of the UK. It is based upon an inefficient and declining industry - agriculture. There is little future in expanding agriculture, and in any case the expansion is certain to reduce the number of people employed and runs counter to nearly 100 years of policy designed to aid peasants and hit the big landlords, who alone have the acreage and wealth to raise productivity. Extreme protection has led to a few small and highly-inefficient locally based industries. This has raised the price level and (by depressing real wages) adds to the emigration probably more than the employment it gives retards emigration. Indeed without emigration the Irish would starve. Recurrent crises plus the development of the Common Market have led to a reversal of the protectionist policy; and the only alternative appears to be complete free-trade and laissez-faire. (Already with hardly any defense expenditures Irish taxation is as heavy as the UK's!) The reversal of policy has been accompanied by a withdrawal from the Celtic Twilight - tho' Irish is still the medium of instruction in schools and the official language; the Church still dominates to an incredible extent; but Ireland is trying to come back to reality. The Border has been declining as an issue, (The North is incomparably more prosperous) and the Irish are just beginning to see that nobody cares whether they live or die - they are (as I hope to show) a net charge to the UK. Problem is therefore how to raise themselves by their bootstrap (there is no shortage of capital for profitable ventures). First, clearly get rid of their illusions. Above all, nationalism and Irish mysticism. Next that all the world loves them and hates the English, and that Northern Ireland is languishing under oppression (fewer than 10\% voted Nationalist in the October 1959 general election). Then that agriculture plus protection equal a rising standard of living. Lastly, and above all, that emigration is a 'Bad Thing'. Already Lemass, the Prime Minister, Dillon, the Leader of the Opposition, and a few others are feeling their way towards this point of view. They are handicapped by a lack of informed public support (the press is still uniformly nationalist), but the top civil servant - T.H. Whitaker, Dept. of Finance - their head economist, McCarthy at the Dept. of Statistics - their adviser, Patrick Lynch, chairman of Aer Lingus and people like Senator (Professor) George O'Brien of U.C.D., say all these things in private. The Irish assets are a stable government, an excellent civil and foreign service, and a great band of intelligent and well-educated people to call on. The Church also at its top levels is antinationalist since, clearly it is better for them to be a big minority in the U.K. than an overwhelming majority in a tin-pot little state nobody gives a tuppeny damn about. The local priests are, of course, baboons. The nuns are worse. They are responsible for the terrible system of education and the incredible population picture (lowest marriage-rate and lowest birthrate in Europe!).

2) There are 4 Universities - Cork and Galway are tiny, and while having some good people are far too small and hopelessly poor. U.C.D. (Catholic) is big, poor and overwhelmed with evening students. The clerical element is extremely strong. T.C.D. (Protestant) is poor, has high standards, but is distrusted by the government, and has an enormous number of overseas students. Clearly the two should be united. For example, TCD has 4 economists and UCD has 5 or 6; they all teach inordinately, their salaries are so low that they have to hold innumerable jobs, and hardly any of them do any research. They are almost completely out of touch with recent economics in the U.K. In contrast, Queen's, Belfast, pays the highest salaries in the 
British Isles, has vast sums for research and is fully in the mainstream of British academic life. It is also quite non-sectarian, and supported lavishly by the Northern Irish government. Further in N. Ireland the university crowns a lavish system of education now almost up to English standards (Please see the relevant chapter of my book) while in the Republic the education system is the worst in Western Europe in the opinion of OEEC officials. Nevertheless the innate quality of the academic staff is high (no other employment opportunities probably explains a lot) and many of them have trained in the U.S. and U.K. at one stage or other. What they need is time and money; probably the way to this is to reduce student enrollments, raise secondary standards and to help raise salaries by bigger government grants.

3) In this connexion hopeful and helpful people include those already mentioned plus the economics staffs of UCD and TCD - most especially George O'Brien and (above all) Patrick Lynch. They are linked with Whitaker, McCarthy and others in the Statistical Society, but they lack (1) coherent research (2) a forum for debate and dissemination of their ideas \& (3) outside informed experts except Charles Carter (formerly of Belfast, now Professor of Economics at Manchester, our No. 4 university after Oxford, Cambridge and London) and modestly! myself.

4) This is where the proposed Institute comes in. Its aim is to work on periodic reports on the state of the Irish economy and long-term studies etc., using a small permanent staff as a nucleus, providing a place for civil servants and university people to come for research assistance, and to act cooperatively. Above all it will be a means of educating the informed public (members of the Dail included) in the realities of the Irish situation, and bringing over foreign experts.

5) High upon this list is education. In its present state it is an immense handicap to the country and above all to the individual emigrant who can only go to England in an unskilled capacity. Now this is not overcome by agricultural education (in (1) above I argued that the numbers of rural workers are bound to fall) or by management education. It is only overcome by a real educational effort. In the 6 years I have been going to Dublin, an empty field on the outskirts has still had the sign 'Site of Dublin's new technical high school'. It is still a field uncultivated at that. A head-on collision with the Church must be avoided. Lynch and I are keen that the Institute should do a study of economics of Irish education; and a comparative study with N. Ireland (on the basis of my own work). I think that I could probably supervise this work (given the funds) and that it would provide the basis for a beginning of an attack. The next would be a study of Roman Catholic schools in England and Ireland; in the U.K. they are lavishly supported and rigorously controlled. Therefore Catholicism is not necessarily equal to anti-educational feelings.

I don't know whether this is enough background. I am having some documents sent to you in the U.S., and will get on with a further letter to you. I have to go to a meeting. Meanwhile I'll get some more written for you.

As ever,

John Vaizey 